\title{
Analisis Butir Soal Ujian Akhir Semester Mata Pelajaran Bahasa Inggris Kelas VII SMPN 2 Tegalsiwalan
}

\author{
Putu Ngurah Rusmawan ${ }^{1}$ \\ 1) STKIP PGRI Pasuruan, JI. Ki Hajar Dewantara No.27-29, Pasuruan, Indonesia \\ e-mail: ${ }^{1)}$ afatah72@gmail.com
}

\begin{abstract}
Abstrak
Tujuan dari penelitian ini adalah untuk mendeskripsikan validitas isi, reliabilitas, tingkat kesukaran, tingkat diskriminasi dan distraktor atau pengecoh dari butir soal UAS Mata Pelajaran Bahasa Inggris siswa kelas VII SMPN 2 Tegalsiwalan tahun pelajaran $2015 / 2016$. Jenis penelitian ini adalah deskriptif kuantitatif karena penilitian ini difokuskan pada analisa konten. Subject dalam penelitian ini adalah seluruh siswa SMPN 2 Tegalsiwalan. Object dalam penelitian ini diambil dari soal ujian akhir semester berbentuk pilihan ganda. Teknik pengumpulkan data menggunakan metode observasi dan metode dokumentasi untuk mengetahui deskripsi mengenai hasil evaluasi belajar siswa. Instrumen dalam penelitian ini adalah peneliti sendiri sebagai instrumen utama. Berdasarkan penelitian yang telah dilakukan dapat diketahui bahwa validitas isi pada butir soal pilihan ganda mempunyai tingkat kesesuaian yang cukup tinggi dengan indikator pada silabus dan kurikulum. Hal ini telah dibuktikan dengan analisa pemetaan konten silabus. Reliabilitas butir soal dianalisis dengan menggunakan rumus KR-20 adalah 0,88. Reliabilitas butir soal pilihan ganda memiliki korelasi yang tinggi. Tingkat kesulitan butir soal dari keseluruhan butir soal yang memenuhi persyaratan kelayakan sebesar $55 \%$. Tingkat diskriminasi butir soal dari keseluruhan butir soal yang memenuhi syarat tingkat diskriminasi sebesar 0,25. Distraktor pilihan ganda butir soal sudah diatas $5 \%$ yaitu $16,7 \%$

Kata kunci: Analisis Butir Soal; Validitas Isi; Reliabelitas
\end{abstract}

\section{Test Item Analysis on English Final Test of the Seventh Grade Students at SMPN 2 Tegalsiwalan}

\begin{abstract}
The purpose of this study is to describe the content validity, reliability, item difficulty level, discrimination level and distractor of English final test of the seventh grade students, SMPN 2 Tegalsiwalan in the school year 2015/2016. This type of research was descriptive quantitative focusing on content analysis. Subject in this study was all of students SMPN 2 Tegalsiwalan. The object in this research was taken from the final exams in the forms of multiple choice. The data were collected by using observation and documentation in an attempt to know description about the result of student learning evaluation. The instrument in this study was the researcher himself as the main instrument. The results show that the content validity on multiple choice items have a high level of suitability with the indicators on English subject syllabus and curriculum. It can be seen from the mapping of syllabus content. The reliability of the item that is analyzed by using KR-20 formula is 0.88 . The reliability of multiple choice items has a high correlation. The item difficulty level meets the $55 \%$ eligibility requirements. The degree of discrimination of the items from the whole item meets the requirement. The discrimination level is 0.25 . Distractor of multiple choice item is 16,7 $\%$ fulfilling the requirement of above $5 \%$.
\end{abstract}

Keywords: Item Analysis; Content Validity; Realibility. 


\section{Pendahuluan}

Butir soal adalah komponen utama dalam sistem evaluasi terhadap hasil belajar siswa di sekolah. Menurut tuckman (1975) butir soal yang layak diujikan adalah butir soal yang merefleksikan isi silabus, keterampilan, indikator, tujuan pembelajaran dan semua materi telah diajarkan dan dipelajari. Susanto (2010) menyarankan agar pendidik membuat peta konten analisis kesesuain soal dengan indikator pada silabus. Pendidik dapat membuat korespondensi antara garis besar isi tes dengan tujuan pembelajaran yang terdapat pada silabus. Pemetaan isi soal adalah pencocokan atau penyesuaian dari isi butir soal mengenai apa yang diukur dengan tujuan pembelajaran dan indikatr silabus untuk dipelajari. Butir tes yang telah disesuaikan dapat diujikan karena telah memenuhi unsur kriteria validitas isi.

Reliabilitas sangat penting dalam standar pengukuran soal. Reliabilitas adalah tingkat kepercayaan dari suatu alat ukur (Depdikbud: 1997). Reliabilitas dapat juga diartikan ketepatan tes dalam standar pengukurannya. Reliabilitas merupakan kestabilan skor yang didapat oleh siswa dengan hasil yang sama ketika diuji ulang. Hasil pengukuran tidak akan berbeda apabila didalam proses pengukuran tersebut diujikan kembali karena tingkat konsistensi terhadap hasil dua pengukuran adalah hal yang sama.

Menurut Asmawi (1997) tingkat kesukaran butir soal adalah proporsi peserta tes menjawab benar terhadap butir soal tersebut. Analisis tingkat kesulitan soal adalah mengkaji soal tes dari segi kesulitannya sehingga butir soal dapat digolongkan mana yang termasuk mudah, sedang, dan sukar. Sedangkan daya pembeda adalah kemampuan tes dalam membedakan siswa yang termasuk ke dalam kategori rendah dan kategori tinggi prestasinya (Djiwandono, 1996). Analisis tingkat diskriminatif merupakan mengkaji butir soal dengan tujuan untuk mengetahui kemapuan soal dalam membedakan siswa yang tergolong prestasinya bagus dengan siswa yang tergolong kurang prestasinya. Semakin tinggi indeks tingkat diskriminatif butir soal berarti semakin mampu soal yang dalam membedakan siswa yang telah menguasai materi dengan siswa yang belum menguasai materi

Tujuan utama dari pemasangan distraktor atau pengecoh pada setiap butir soal adalah agar para siswa yang mengikuti ujian akhir semester tertarik untuk memilih jawaban yang salah, karena mereka mengira bahwa distraktor yang mereka pilih itu merupakan jawaban benar. Jika siswa banyak yang memilih distraktor tersebut sebagai jawaban, berarti distraktor tersebut berfungsi dengan baik. Namun sebaliknya, jika sedikit siswa yang terkecoh dengan distraktor, maka semakin kurang distraktor tersebut berfungsi. Menurut Depdikbud (1993: 27) sebuah distraktor dapat dikatakan berfungsi dengan baik jika dipilih oleh paling sedikit 5\% untuk 4 pilihan jawaban dan 3\% untuk 5 pilihan jawaban. Distraktor yang tidak memenuhi kriteria tersebut sebaiknya diganti dengan distraktor lain yang mungkin lebih menarik minat peserta tes ujian akhir sesmester untuk memilihnya.

Para pendidik perlu meningkatkan kualitas butir soal melalui analisis validitas isi, reliabilitas, tingkat kesukaran, tingkat diskriminasi, dan distraktor karena Kelima komponen tersebut sangatlah penting untuk dijadikan konsep dasar untuk, mendeskripsikan, mengklasifikasikan, dan menganalisis soal-soal yang tidak relevan pada penggunaannya. Penelitian ini bertujuan untuk mendiskripsikan validitas, reliabilitas, tingkat kesukaran butir soal, daya pembeda, dan distraktor pada butir soal 
UAS Mata Pelajaran Bahasa inggris siswa kelas VII SMPN 2 Tegalsiwalan tahun pelajaran 2015/2016

\section{Metode Penelitian}

Jenis penelitian ini menggunakan pendekatan deskriptif kuantitatif. prosedur penelitian yang dihasilkan adalah data kualitatif berupa deskripsi pemetaan validas isi berdasarkan kesesuaian isi soal dan silabus data dan data kuantitatif berupa angkaangka dari hasil penghitungan realibitas, analisa tingkat kesulitan soal, tingkat diskriminatif, dan distraktor butir soal. Penelitian ini dimulai dari pengumpulan data, interpretasi terhadap data tersebut, serta penampilan data dari hasil penelitian menggunakan angka-angka statistik.

Sumber data adalah subjek dari mana data itu diperoleh (Arikunto 2013: 172). Sumber data dalam penelitian ini adalah dokumen soal ujian akhir semester Data dalam penelitian ini adalah soal UAS Mata Pelajaran Bahasa inggris siswa kelas VII SMPN 2 Tegalsiwalan tahun pelajaran 2015/2016. Subjek pada penelitian ini adalah seluruh siswa kelas VII.

Teknik pengumpulkan data menggunakan metode observasi dan metode dokumentasi untuk mengetahui gambaran secara kongkrit mengenai evaluasi belajar siswa. Instrumen dalam penelitian ini adalah peneliti sendiri sebagai instrumen utama (Human instrument) adalah peneliti sendiri sebagai instrumen utama yang menetapkan fokus penelitian, memilih informan sebagai sumber data, melakukan pengumpulan data, menilai kualitas data, analisis data, enafsirkan data dan membuat kesimpulan atas temuannya (Sugiyono, 2013: 306).

Teknik analisis data mengunakan deskriptif kuantitatif. Menurut Sugiyono (2003: 11) Penelitian diskriptif adalah penelitian yang dilakukan untuk mengetahui nilai variabel mandiri, baik satu variabel atau lebih tanpa membuat perbandingan, atau menghubungkan dengan variabel yang lain. Sugiyono menambahkan (2003:14) Penelitian kuantitatif adalah penelitian dengan memperoleh data yang berbentuk angka atau data kualitatif yang diangkakan.

Penelitian in merupakan deskriptif kuantitatif karena hasil analisis data dalam penelitian ini dengan mendeskripsikan hasil analisis mengenai butir soal ulangan akhir semester mata pelajaran. Setelah hasil pekerjaan siswa di nilai, kemudian nilai tersebut disajikan dalam bentuk data yang digunakan untuk mengetahui kualitas butir soal.

\section{Hasil dan Pembahasan}

Hasil analisis data dalam penelitian ini dengan mendeskripsikan hasil analisis mengenai butir soal UAS Mata Pelajaran Bahasa inggris siswa kelas VII SMPN 2 Tegalsiwalan. Analisis data telah dilakukan untuk menjawab masalah penelitian. Pada bagian ini menyajikan beberapa hal mengenai validitas isi, reliabilitas, tingkat kesulitan butir tes, daya pembeda, dan butir pengecoh atau distraktor dalam pertanyaan pilihan ganda berdasarkan pada hasil temuan sehubungan dengan literatur terkait

\section{Validitas isi Butir Soal}

Hasil analisis validitas isi pada butir soal yang mempunyai validitas cukup tinggi dengan jumlah 50 butir soal. Validitas isi soa dan uraian silabus mempunyai kesejajaran dan ada pula yang tidak sejajar dengan kurikulum. Butir soal yang 
mempunyai kesejajaran terhadap kurikulum butir soal. Berikut ini hasil pemetaan analisa kesesuaian isi butir tes dengan silabus.

Tabel 1. Kesesuaian butir soal dengan silabus

\begin{tabular}{|c|c|c|c|c|c|c|c|}
\hline \multicolumn{2}{|r|}{$\begin{array}{l}\text { Indikator silabus } \\
\text { kurikulum }\end{array}$} & \multicolumn{5}{|c|}{ Nomor soal } & \multirow{2}{*}{$\begin{array}{l}\text { Bentuk soal } \\
\text { Pilihan ganda }\end{array}$} \\
\hline 1 & $\begin{array}{l}\text { Meminta dan } \\
\text { memberi barang }\end{array}$ & 1 & 4 & 5 & 23 & & \\
\hline 2 & $\begin{array}{l}\text { Meminta dan } \\
\text { memberi jasa }\end{array}$ & 44 & 46 & & & & Pilihan ganda \\
\hline 3 & $\begin{array}{l}\text { memberi } \\
\text { pendapat }\end{array}$ & 3 & 36 & 37 & & & Pilihan ganda \\
\hline 4 & $\begin{array}{l}\text { Menyatakan suka } \\
\text { dan tidak suka }\end{array}$ & 2 & 41 & 42 & & & Pilihan ganda \\
\hline 5 & $\begin{array}{l}\text { Meminta } \\
\text { klarifikasi }\end{array}$ & 43 & & & & & Pilihan ganda \\
\hline 6 & pengumuman & 16 & 17 & 18 & & & Pilihan ganda \\
\hline 7 & Daftar belanja & 19 & 20 & 21 & 22 & & Pilihan ganda \\
\hline 8 & instruksi & 24 & 25 & 45 & & & Pilihan ganda \\
\hline 9 & deskripsi & 6 & 7 & 8 & 9 & 10 & Pilihan ganda \\
\hline 10 & deskripsi & 26 & 27 & 28 & 29 & 30 & Pilihan ganda \\
\hline 11 & prosedur & 38 & 39 & 40 & & & Pilihan ganda \\
\hline 12 & prosedur & 11 & 12 & 13 & 14 & 15 & Pilihan ganda \\
\hline 13 & prosedur & 31 & & & & & Pilihan ganda \\
\hline 14 & deskripsi & 47 & 48 & 49 & 50 & & Pilihan ganda \\
\hline
\end{tabular}

Brown (2002: 23-24) menyatakan bahwa ahli harus melihat apakah isi tes mewakili keterampilan yang seharusnya diukur. Hal ini melibatkan konsistensi antara isi silabus, tujuan tes, dan isi tes. Jika kesesuaian isi adalah tujuan yang merupakan perwakilan dari silabus, dapat dikatakan bahwa tes tersebut memperhatikan validitas isi. Dari hasil analisis, peneliti menemukan bahwa 47 item sesuai dengan silabus dan 3 item tidak termasuk dalam kompetensi dasar. Singkatnya, tes dapat dikatakan memiliki validitas isis yang tinggi karena 3 item adalah item tidak valid dan 47 item adalah item yang valid.

\section{Reliabilitas Soal Pilihan Ganda}

Hasil analisis reliabilitas butir soal pilihan ganda dengan rumus KR-20 sebesar 0,88 . Reliabilitas 0,88 dapat diinterpretasikan bahwa tingkat realibilitas soal UAS Mata Pelajaran Bahasa inggris siswa kelas VII SMPN 2 Tegalsiwalan tahun pelajaran 2015/2016 memiliki tingkat realibilitas yang sangat tinggi.

Menurut Brachman (2004: 153) menyatakan bahwa reliabilitas adalah konsistensi pengukuran di berbagai kondisi dalam prosedur pengukuran. Administrasi tes harus konsisten. Tes dapat dikatakan sebagai tes yang terorganisir dengan baik, jika hasilnya antara 0-1 yang berarti skor stabil. Tes tidak bisa mengukur apa pun dengan baik kecuali jika diukur secara konsisten. Dari skor alpha cronbach, realibilitas tes akhir Bahasa Inggris tinggi hasilnya adalah 0,88. Jadi, realibilitas Ujian Akhir Bahasa Inggris di SMP tegal siwalan tinggi. 
3. Taraf Kesulitan Butir Soal

Hasil analisis taraf kesulitan terdapat 30 butir soal yang sangat mudah yaitu nomor $1,2,3,4,6,8,10,11,12,14,15,16,19,20,21,22,25,27,31,33,32,34,35,36,41,42,43$ ,44,46, dan 47. Hampir keseluruhan siswa dapat menjawab dengan benar karena jumlah jawaban benar yang dihasilkan oleh siswa cukup banyak. Terdapat 18 butir soal yang sangat sulit yaitu nomor 7,9, 13,17,18,23,24,26,28,29,37,38,39,40,45,48,49, dan 50 . Hampir tidak ada seorang siswa dapat menjawabnya dengan benar. Butir soal kesuluruhan ada 50 soal yaitu dengan rincian: $P=(J J B: J P T) \times 100 \%$

Tabel 2. Analisa tingkat kesulitan butir tes

\begin{tabular}{|c|c|c|c|}
\hline Nomor soal & Jumlah jawaban benar & $\begin{array}{l}\text { tingkat kesulitan } \\
\text { butir tes }(p)\end{array}$ & $\begin{array}{c}\text { persentase tingkat } \\
\text { kesulitan }\end{array}$ \\
\hline 1 & 18 & 0,6 & $60 \%$ \\
\hline 2 & 21 & 0.7 & $70 \%$ \\
\hline 3 & 26 & 0.87 & $86.7 \%$ \\
\hline 4 & 21 & 0.7 & $70 \%$ \\
\hline 5 & 15 & 0.5 & $50 \%$ \\
\hline 6 & 25 & 0.83 & $83.3 \%$ \\
\hline 7 & 14 & 0.47 & $46.7 \%$ \\
\hline 8 & 18 & 0.6 & $60 \%$ \\
\hline 9 & 8 & 0.27 & $26.7 \%$ \\
\hline 10 & 27 & 0.9 & $90 \%$ \\
\hline 11 & 20 & 0.67 & $66.7 \%$ \\
\hline 12 & 22 & 0.73 & $73.3 \%$ \\
\hline 13 & 12 & 0.4 & $40 \%$ \\
\hline 14 & 17 & 0.57 & $56.7 \%$ \\
\hline 15 & 20 & 0.67 & $66.7 \%$ \\
\hline 16 & 16 & 0.53 & 53.3 \\
\hline 17 & 10 & 0.33 & $33.3 \%$ \\
\hline 18 & 6 & 0.2 & $20 \%$ \\
\hline 19 & 26 & 0.87 & $86.7 \%$ \\
\hline 20 & 29 & 0.97 & $96.7 \%$ \\
\hline 21 & 19 & 0.63 & $63.3 \%$ \\
\hline 22 & 18 & 0.6 & $60 \%$ \\
\hline 23 & 13 & 0.43 & 43.3 \\
\hline 24 & 19 & 0.63 & $63.3 \%$ \\
\hline 25 & 19 & 0.63 & $63.3 \%$ \\
\hline 26 & 12 & 0.4 & $40 \%$ \\
\hline 27 & 28 & 0.93 & $93.3 \%$ \\
\hline 28 & 12 & 0.4 & $40 \%$ \\
\hline 29 & 11 & 0.37 & $36.7 \%$ \\
\hline 30 & 15 & 0.5 & $50 \%$ \\
\hline 31 & 25 & 0.83 & $83.3 \%$ \\
\hline 32 & 16 & 0.53 & $53.3 \%$ \\
\hline 33 & 16 & 0.53 & $53.3 \%$ \\
\hline 34 & 18 & 0.6 & $60 \%$ \\
\hline 35 & 21 & 0.7 & $70 \%$ \\
\hline 36 & 21 & 0.7 & $70 \%$ \\
\hline 37 & 9 & 0.3 & $30 \%$ \\
\hline 38 & 1 & 0.03 & $3.33 \%$ \\
\hline 39 & 1 & 0.03 & $3.33 \%$ \\
\hline 40 & 10 & 0.33 & $33.3 \%$ \\
\hline 41 & 19 & 0.63 & $63.3 \%$ \\
\hline 42 & 17 & 0.57 & $56.7 \%$ \\
\hline
\end{tabular}




\begin{tabular}{cccc}
\hline 43 & 24 & 0.8 & $80 \%$ \\
\hline 44 & 16 & 0.53 & $53.3 \%$ \\
\hline 45 & 7 & 0.23 & $23.3 \%$ \\
\hline 46 & 18 & 0.6 & $60 \%$ \\
\hline 47 & 23 & 0.77 & $76.7 \%$ \\
\hline 48 & 14 & 0.47 & $46.7 \%$ \\
\hline 49 & 8 & 0.27 & $26.7 \%$ \\
\hline 50 & 6 & 0.2 & $20 \%$ \\
\hline
\end{tabular}

Sehinggga dapat diperoleh hasil dengan Jumlah $\mathrm{P}$ keseluruhan adalah 27,55: $50 \times 100 \%=55 \%$ dengan demikian dapat diinterpretasikan tingkat kesulitan adalah sedang. Menurut Arikunto (2007: 207) pertanyaan yang bagus tidak mudah dan tidak terlalu sulit. Pertanyaan yang mudah tidak akan merangsang siswa untuk meningkatkan kekuatan mereka dalam memecahkan masalah. Dan pertanyaan yang sulit akan membuat para siswa tidak semangat mencoba untuk memecahkan masalah itu pada pertanyaan. Jadi, soal itu tidak bisa sangat mudah atau sulit bagi siswa karena siswa harus memiliki semangat dalam belajar bahasa Inggris.

Arikunto (2003) menyatakan bahwa tes disebut sulit jika indeksnya antara 0,00 0,20 . Item tes dalam rentang moderat jika indeks kesulitannya adalah antara 0,21 - 0,70. Kemudian, ini disebut uji mudah jika indeksnya antara 0,70 - 1,00. dari analisis yang ada dalam soal (UAS) terdapat 27 item mudah. Ada 23 item yang sulit, Jadi, berdasarkan pernyataan di atas, dapat dikatakan bahwa item Tes Akhir Bahasa Inggris (UAS) di SMP tegal siwalan sedang dan itu berarti tes baik. Berdasarkan persentase taraf kesulitan, $55 \%$ adalah moderat dan $45 \%$ adalah item yang sulit.

\section{Tingkat diskriminasi Butir Soal}

Hasil analisis tingkat diskriminasi butir soal pilihan ganda yaitu Untuk Kelompok tinggi $27 \%$ × $30=8,1$ Kelompok rendah $27 \% \times 30=8,1$ maka siswa maka ditetapkan disini jumlah kelompok tinggi dan rendah 16 orang. Sehingga dihitung dengan rumus sebagai berikut:

$$
\begin{aligned}
& D=(T-R): N \\
& D=(6-2): 16 \\
& D=0,25
\end{aligned}
$$

Sehingga dapat dideskripsikan dari hasil analisis tingkat diskriminasi butir soal adalah tingkat sedang yaitu sebesar 0,25 karena karena hasil lebih dari 0,20. Daya pembeda bertujuan untuk membedakan siapa yang merupakan kelompok atas siswa yang baik dan kelompok siswa rendah yang lebih rendah dari tes. Skor yang bagus untuk siswa yang berprestasi tinggi di setiap butir tes. Menurut Huges (2005: 226) daya pembeda adalah sejauh mana suatu butir tes membedakan antara peserta tes berkemampuan tinggi dan kemampuan rendah. Daya pembeda itu penting karena jika butir soal dapat membedakan lebih banyak, mereka akan lebih dapat diandalkan. Menurut Arikunto (2007: 213) daya pembeda mendeskripsikan seberapa baik item tersebut berfungsi dalam memisahkan siswa yang lebih baik dari siswa yang lebih rendah. Jika siswa yang baik cenderung mengerjakan dengan baik pada butir tes dan 
siswa rendah melakukan hal yang buruk pada item yang sama, maka item itu bagus karena membedakan siswa yang baik dari siswa yang buruk.

\section{Distraktor}

Hasil analisis distraktor soal multiple choice item dengan item sebanyak 50 butir soal, dimana setiap butir soal dilengkapi dengan 4 alternatif, yaitu $A, B, C$, dan D . Dari 50 butir item tersebut, khusus untuk butir item nomor 1,2 dan 3 diperoleh pola penyebaran jawaban item sebagai berikut :

Tabel 3. distraktor pada butir soal

Nomor Butir item Alternatif ( Options )

Keterangan

\begin{tabular}{ccccc}
\cline { 2 - 5 } & A & B & C & D \\
\hline 1 & 18 & 5 & 5 & 6 \\
\hline 2 & 4 & 21 & 3 & 3 \\
\hline 3 & 1 & 2 & 26 & 1
\end{tabular}$\quad$ ( ) : Kunci jawaban

Dengan pola penyebaran jawaban item sebagaimana tergambar pada tabel analisis di atas, maka dengan mudah dapat kita ketahui berapa persen teste yang telah "terkecoh" untuk memilih distraktor yang dipasangkan pada item 1, 2 dan 3. Sebagai contohnya untuk item nomor 1 adalah sebagai berikut :

Untuk item nomor 1: Kunci jawaban adalah $\mathrm{A}$, sedangkan pengecoh atau distraktornya adalah , B, C dan D. Pengecoh B di pilih oleh 5 orang siswa, berarti $5 / 30 \mathrm{x}$ $100 \%=16,7 \%$. Jadi, pengecoh B sudah dapat menjalankan fungsinya dengan baik. Sebab, angka persentasenya sudah melebihi $5 \%$. Persentase pengecoh $\mathrm{C}$ diperoleh sebesar $16,7 \%$, pengecoh D $20 \%$, . Jadi, ketiga pengecoh yang dipasangkan pada item nomor 1 sudah dapat menjalankan fungsinya dengan baik sebagai distraktor. Untuk item 2 dan 3 dapat pula dilakukan analisis fungsi distraktor dengan cara yang sama seperti halnya item nomor 1. Dalam bentuk tes pilihan ganda, untuk setiap item telah dilengkapi dengan beberapa kemungkinan jawaban. Menurut Bachman (2004) analisis distraktor memberikan ukuran seberapa baik masing-masing opsi yang salah berkontribusi pada kualitas item pilihan ganda. Dengan hasil analisis, item distractor dalam tes dikategorikan sangat baik karena 49 item termasuk antara 76\% - 125\%. Kemudian pada tes tipe 2-4 juga dikategorikan distraktor yang sangat baik, karena 46 item termasuk antara $76 \%$ - 125\%. Kesimpulannya pada tes tersebut dikategorikan sebagai distraktor yang sangat baik.

Berdasarkan penelitian sebelumnya Rusmawan (2015) pada item analisis tes akhir ujian bahasa Inggris 2015 untuk di SMP kemala bhayangkari 10 porong telah disimpulkan tes bahasa Inggris yang baik dalam validitas konten pada tes tipe $A$. Realibilitas dalam tes tipe A tinggi, tetapi pada tes tipe $B$ rendah. Taraf Kesulitan item dalam tipe $A$ dan $B$ adalah moderat dan daya pembeda tes cukup baik dalam tes tipe $A$ dan B. Namun, berdasarkan temuan dan diskusi dari penelitian ini menunjukkan hasil yang berbeda. Penelitian ini telah dilakukan di SMP Tegal Siwalan dengan 4 jenis tes tetapi sebenarnya itu adalah 2 jenis tes. Tes tipe 1-2 bagus dalam validitas konten, kesulitan item, dan distraktor item, dan kekuatan diskriminatif. Hasil serupa dalam tes tipe 1-2 dengan studi sebelumnya dalam tes tipe A baik dalam validitas isi, kesulitan 
item, dan daya pembeda yang baik. Hasil yang berbeda adalah butir pengecoh dalam penelitian sebelumnya tidak ada analisis distraktor item.

\section{Kesimpulan}

Berdasarkan hasil penelitian yang telah dipaparkan diatas maka dapat ditarik kesimpulan sebagai berikut. Validitas butir soal memenuhi syarat dan kelayakan validitas isi dengan jumlah 50 butir soal. Butir soal yang memenuhi kriteria validitas isi dari soal pilihan ganda memiliki kesejajaran terhadap indikator silabus dan kurikulum. Reliabilitas butir soal pilihan ganda dengan rumus KR-20 adalah sebesar 0,88. Reliabilitas 0,88 memiliki kestabilan yang sangat tinggi. Soal UAS mata pelajaran Bahasa inggris yang dikerjakan para siswa yang memenuhi syarat tes yang baik sebesar $88 \%$ dengan jumlah 50 butir soal. Taraf Kesukaran Butir Soal dari keseluruhan butir soal yang memenuhi persyaratan kelayakan sebesar $55 \%$. Tingkat diskriminatif butir soal soal telah memenuhi syarat di atas 0,20 yaitu sebesar 0,25 sedangkan untuk distraktor butir soal telah berfungsi cukup baik yaitu sebesar $16,7 \%$.

\section{Daftar Pustaka}

Asmawi, Z. et.all. (1997). Penilaian Hasil Belajar. Pusat Antar Universitas, Direktorat Jenderal Pendidikan Tinggi: Departemen PendidikanDan kebudayaan.

Arikunto, S. (2013). Prosedur Penelitian Suatu Pendekatan Praktik. Jakarta: Rineka Cipta.

Bachman, L.F. (2004). Fundamental Considerations in Language Testing. Oxford: Oxford University Press.

Brown H. (2004). Principle language assessment: principle and classroom practice. Longman: New York

Departemen Pendidikan Dan Kebudayaan. (1997). Manual Item And Test Analysis Iteman. Badan Penelitian dan Pengembangan Pendidikan dan Kebudayaan: Pusat Penelitian dan Pengembangan Sistem Pengujian.

Djiwandono, M. (1996). Tes Bahasa dalam Pengajaran. Bandung:ITB

Sugiyono. (2013). Metode Penelitian Pendidikan Pendekatan Kuantitatif, kualitatif, dan $R \& D$. Bandung: Alfabeta.

Rusmawan, P. N. (2015). An Analysis Content Validity of Formative Test Item. Journal of education linguistics and literature Vol. 2, No.1 (2015).

Susanto, S.(2010). Syllabus dan RPP. Surabaya: Unesa Universty Press.

Tuckman, B. W. (1975). Measuring Educational Outcome: Fundamental of testing. New York: Harcourt Brace Jovanovich, Inc. 